Article

\title{
Preparation of Copper Nitride Films with Superior Photocatalytic Activity through Magnetron Sputtering
}

\author{
Aihua Jiang ${ }^{1}$, Hongjuan Shao ${ }^{1}$, Liwen Zhu ${ }^{1}$, Songshan $\mathrm{Ma}^{2}$ and Jianrong Xiao ${ }^{1,2, * \mathbb{C}}$ \\ 1 College of Science, Guilin University of Technology, Guilin 541004, China; jah@glut.edu.cn (A.J.); \\ 2004134@glut.edu.cn (H.S.); zhuliwen1995@163.com (L.Z.) \\ 2 School of Physics and Electronics, Central South University, Changsha 410083, China; songshan@csu.edu.cn \\ * Correspondence: xjr@glut.edu.cn
}

Received: 21 August 2020; Accepted: 25 September 2020; Published: 28 September 2020 updates

\begin{abstract}
TiO}_{2}$ possesses a wide forbidden band of about $3.2 \mathrm{eV}$, which severely limits its visible light absorption efficiency. In this work, copper nitride $\left(\mathrm{Cu}_{3} \mathrm{~N}\right)$ films were prepared by magnetron sputtering at different gas flow ratios. The structure of the films was tested by scanning electron microscope, X-ray diffractometer, and X-ray photoelectron spectroscope. Optical properties were investigated by UV-vis spectrophotometer and fluorescence spectrometer. Results show that the $\mathrm{Cu}_{3} \mathrm{~N}$ crystal possesses a typical anti- $\mathrm{ReO}_{3}$ crystal structure, and the ratio of nitrogen and $\mathrm{Cu}$ atoms of the $\mathrm{Cu}_{3} \mathrm{~N}$ films was adjusted by changing the gas flow ratio. The $\mathrm{Cu}_{3} \mathrm{~N}$ films possess an optical band gap of about $2.0 \mathrm{eV}$ and energy gap of about $2.5 \mathrm{eV}$ and exhibit excellent photocatalytic activity for degrading methyl orange (degradation ratio of $99.5 \%$ in $30 \mathrm{~min}$ ). The photocatalytic activity of $\mathrm{Cu}_{3} \mathrm{~N}$ mainly originates from vacancies in the crystal and $\mathrm{Cu}$ self-doping. This work provides a route to broaden the forbidden band width of photocatalytic materials and increase their photoresponse range.
\end{abstract}

Keywords: $\mathrm{Cu}_{3} \mathrm{~N}$ films; magnetron sputtering; gas flow ratio; photocatalytic activity; methyl orange

\section{Introduction}

The accelerating industrialization has led to rapid increase in pollutant emissions and worsened environmental pollution. Effective methods must be developed to eliminate pollution and protect the environment. To resolve environmental problems, scholars have increasingly focused on semiconductor photocatalysis, which is a safe, simple, and non-secondary green technology. $\mathrm{TiO}_{2}$ exhibits excellent photocatalytic properties and has been widely used in various fields in industry and agriculture [1-5]. However, the photocatalytic material of $\mathrm{TiO}_{2}$ has a narrow photoresponse range (band gap of approximately $3.2 \mathrm{eV}$, which can only absorb ultraviolet light) and low photocatalytic quantum efficiency [2,6-9]. CdS has a small forbidden band width and good matching with the near-ultraviolet light segment in the solar spectrum, but it is prone to photo-corrosion and has a limited service life [9-13]. Therefore, in research of film materials, exploratory work on photocatalytic performance is of considerable importance.

Copper nitride $\left(\mathrm{Cu}_{3} \mathrm{~N}\right)$ possesses a special anti- $\mathrm{ReO}_{3}$ lattice structure, and the central vacancies of the lattice are easily filled by other atoms, leading to changes in the electrical properties and the feasibility of the crystal to be used from the insulator to the conductor [14-21]. At present, research on $\mathrm{Cu}_{3} \mathrm{~N}$ films mainly focuses on the influence of preparation parameters on the crystal structure. Changes in the $\mathrm{Cu}_{3} \mathrm{~N}$ structure or doping of elements could lead to alterations in electrical and optical properties [16,21-23]. The band gap of $\mathrm{Cu}_{3} \mathrm{~N}$ films can be adjusted to a relatively large range. Numerous studies have shown that the optical band gap of $\mathrm{Cu}_{3} \mathrm{~N}$ films ranges from $1.1 \mathrm{eV}$ to $1.9 \mathrm{eV}[15,24-26]$ and varies according to experimental conditions and process parameters. In general, many reports have been published on the regulation of the band gap of $\mathrm{Cu}_{3} \mathrm{~N}$ films by doping 
and changing the nitrogen partial pressure $[19,27]$. The intrinsic optical band gap of $\mathrm{Cu}_{3} \mathrm{~N}$ films is $2.6 \pm 0.3 \mathrm{eV}$ [28]. Studies on the application of the $\mathrm{Cu}_{3} \mathrm{~N}$ films have mainly focused on the following aspects: Disposable optical storage materials [29,30], barrier layer of low-reluctance tunnel junction [31], field emission materials [32], and lithium-ion battery materials [33,34]. At present, no related literature reports the use of $\mathrm{Cu}_{3} \mathrm{~N}$ films as photocatalytic materials.

This work studied the catalytic degradation of methyl orange of $\mathrm{Cu}_{3} \mathrm{~N}$ films prepared by magnetron sputtering for the first time and analyzed the catalytic mechanism of the films.

\section{Experiment}

$\mathrm{Cu}_{3} \mathrm{~N}$ films were prepared on single-crystal silicon and quartz (size, $2.5 \mathrm{~cm} \times 1.0 \mathrm{~cm} \times 120 \mathrm{~nm}$ ) substrates by radio frequency (RF) reactive magnetron sputtering (designed and developed by Shenyang Scientific Instrument Co., Ltd., Chinese Academy of Sciences, Shenyang, China) by using a high-purity $\mathrm{Cu}$ target (purity of $99.999 \%$ ) and nitrogen (99.99\%) and argon (99.99\%) as working gases. The monocrystalline silicon wafer (100) and quartz wafer were washed with acetone and alcohol and rinsed repeatedly with deionized water. The substrate was dried in an oven. The substrate was placed on the turntable at the top of the vacuum chamber, and its speed was $30 \mathrm{rpm}$. The distance between the target and the substrate was about $18 \mathrm{~cm}$. The distance between the target and the substrate was about $18 \mathrm{~cm}$. A combination of mechanical pump and molecular pump was used to vacuum. At room temperature, the vacuum degree of the vacuum chamber could reach $1.0 \times 10^{-3} \mathrm{~Pa}$ in about $60 \mathrm{~min}$. The surface of the target was sputter cleaned before deposition. The gas flow ratio $r\left(r=\left[\mathrm{N}_{2}\right] /[\mathrm{Ar}]\right)$ was set to $1 / 1,1 / 2,1 / 3$, and $1 / 6$, and the total gas flow was $40 \mathrm{sccm}$. The gas was precisely controlled by a flow meter, mixed and sent into the vacuum chamber at room temperature. The RF sputtering power was kept constant at $250 \mathrm{~W}$. The deposition pressure was $1.0 \mathrm{~Pa}$, and the deposition time was about $5.0 \mathrm{~min}$. The films thickness was monitored by the EQ-TM106 (Hefei Kejing Material Technology Co. Ltd., Hefei, China) film thickness monitor (with an accuracy of $0.14 \mathrm{~nm}$ ), and they were all controlled at a thickness of about $120 \mathrm{~nm}$.

To judge the photocatalytic activity of the $\mathrm{Cu}_{3} \mathrm{~N}$ films, we compared their catalytic effect with $\mathrm{TiO}_{2}$ films, which were deposited by magnetron sputtering with $\mathrm{TiO}_{2}(99.99 \%)$ as target. The conditions of the $\mathrm{TiO}_{2}$ films samples are as follows: The Ar flow was fixed at $40 \mathrm{sccm}$, and the RF sputtering power, deposition pressure, and deposition time were $250 \mathrm{~W}, 1.0 \mathrm{~Pa}$, and $5.0 \mathrm{~min}$, respectively. During the $\mathrm{TiO}_{2}$ and $\mathrm{Cu}_{3} \mathrm{~N}$ film preparation, the substrate was not heated.

The surface morphology of the $\mathrm{Cu}_{3} \mathrm{~N}$ films was observed by scanning electron microscopy (SEM, JSF-2100, HITACHI, Tokyo, Japany), and the surface energy disperse spectra (EDS) of the films were recorded. The phase composition of the films on the silicon substrate was tested by X-ray diffractometer (XRD, X'pert3 Powder, PANalytical, Lelyweg, the Netherland) using $\mathrm{Cu}-\mathrm{K} \alpha$ radiation $(\lambda=0.154 \mathrm{~nm})$, and the scanning angle range was $20^{\circ}-70^{\circ}$ at a $0.015^{\circ}$ step size. Surface photoelectron spectroscopy of the films was carried out by X-ray photoelectron spectroscope (XPS, ESCALAB 250Xi model, Boston, MA, USA) with a monochromatic Mg-K X-ray source, and the spectra were calibrated by carbon peak C 1s at $284.5 \mathrm{eV}$. Due to the limitation of the experimental conditions, the latest reported method was not used for calibration [35]. The transmission spectrum of the films was recorded using UV-vis spectrophotometer (UV-2700, Shimadzu, Kyoto, Japan) in the wavelength range 300-1200 nm at room temperature. The optical band gap of the films was obtained in accordance with the transmission spectrum of the films combined with extrapolation of the Tauc equation. The photoluminescence (PL) properties of the $\mathrm{Cu}_{3} \mathrm{~N}$ films on silicon wafers were tested using a Cary Eclipse (Agilent Technologies Inc., Santa Clara, CA, USA) fluorescence spectrophotometer with a wavelength of $370 \mathrm{~nm} \mathrm{He}-\mathrm{Cd}$.

In this work, $50 \mathrm{~mL}$ of $20 \mathrm{mg} / \mathrm{L}$ methyl orange solution was used as the target degradation product and $\mathrm{Cu}_{3} \mathrm{~N}$ films with size of $2.5 \mathrm{~cm} \times 1.0 \mathrm{~cm} \times 120 \mathrm{~nm}$ were used as the catalyst. A high-pressure mercury lamp $(500 \mathrm{~W})$ was used as light source (the films were $25 \mathrm{~cm}$ away from the light source). The effect of the films on the photocatalytic degradation of methyl orange was studied. Sampling and 
testing were conducted once every $3 \mathrm{~min}$. The absorbance of the methyl orange solution degraded by the films was recorded using UV-vis spectrophotometer (UV-2700, Shimadzu, Kyoto, Japan).

\section{Results and Discussion}

Figure $1 \mathrm{a}-\mathrm{d}$ shows the surface morphology and cross-section of the SEM image of $\mathrm{Cu}_{3} \mathrm{~N}$ films prepared at different values of $r$. The films prepared have flat and compact surface. However, as $r$ increases, the number of large particles on the films surface increases significantly. The reason may be that as $r$ increases, the content of $\mathrm{Cu}_{3} \mathrm{~N}$ in the films decreases, and the elemental $\mathrm{Cu}$ increases accordingly. When $r$ is low, part of the sputtered $\mathrm{Cu}$ atoms have no time to react with the nitrogen atoms and are deposited on the substrate. Therefore, $\mathrm{Cu}_{3} \mathrm{~N}$ films are mainly formed by forming $\mathrm{Cu}-\mathrm{N}$ bond by absorbing the nitrogen atoms and inserting a lattice of the $\mathrm{Cu}$ atoms. At this time, a considerable part of the $\mathrm{Cu}$ atoms on the surface of the films does not bond to nitrogen. Therefore, the central vacancy of the $\mathrm{Cu}_{3} \mathrm{~N}$ lattice still contains more $\mathrm{Cu}$ atoms. The lattice constant of the $\mathrm{Cu} \mathrm{u}_{3} \mathrm{~N}$ crystal is smaller than that of $\mathrm{Cu}$. Many studies have reported the occurrence of preferential growth in the preparation of $\mathrm{Cu}_{3} \mathrm{~N}$ films by magnetron sputtering $[15,18,27,28,32]$. This preferential growth phenomenon indicates the strong preferential growth mechanism of crystal grains during the growth of the $\mathrm{Cu}_{3} \mathrm{~N}$ films. In addition, the diffusion process causes lattice mismatch stress, resulting in a rough surface morphology. Only when the preferential and diffusion mechanisms during growth reach the equilibrium, the films' surface tends to be flat. The cross-section image (Figure 1e) shows that the $\mathrm{Cu}_{3} \mathrm{~N}$ films are not dense and have some pore defects.

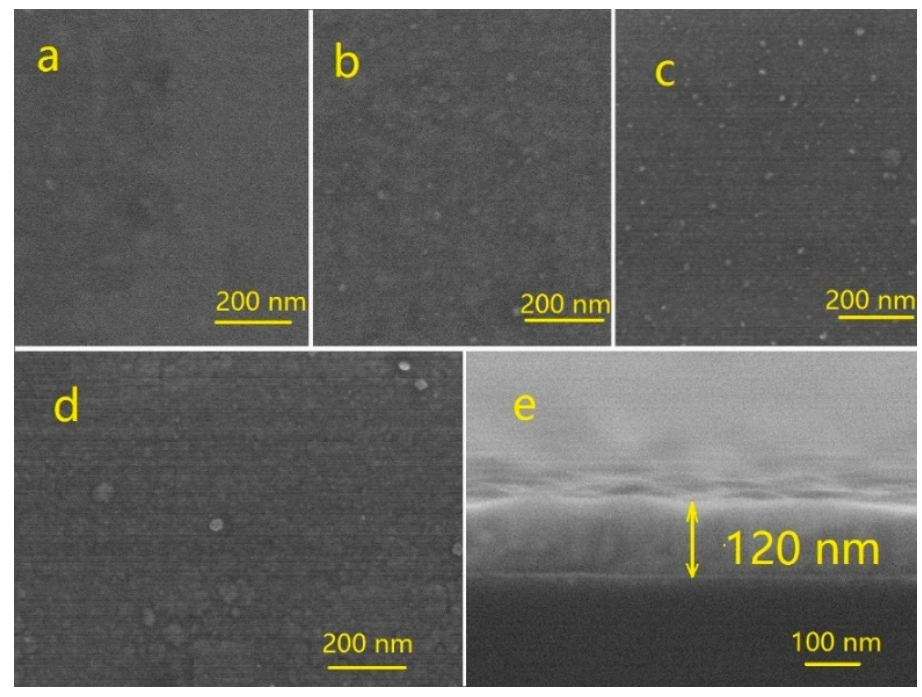

Figure 1. SEM surface morphology of $\mathrm{Cu}_{3} \mathrm{~N}$ films prepared at different: $(\mathbf{a}) r=1 / 6$; (b) $r=1 / 3$, (c) $r=1 / 2$; (d) $r=1 / 1 ;$ (e) cross-sectional morphology of films prepared at $r=1 / 3$.

Figure 2a shows the surface energy disperse spectra (EDS) of $\mathrm{Cu}_{3} \mathrm{~N}$ films prepared at $r=1 / 3$. The atomic percentages of various elements in the films can be obtained (see the insert table in figure). The surface of the films contains low amount of oxygen and carbon contaminations. We believe that it mainly originated from the adsorption of the films surface before the test. In the case of $r=1 / 3$, the $\mathrm{Cu}$ and nitrogen ratio in the films is approximately 3.85:1. The copper-nitrogen atomic ratio value is larger than the copper-carbon ratio of 3:1 in the chemical formula of $\mathrm{Cu}_{3} \mathrm{~N}$, indicating the presence of $\mathrm{Cu}$-rich atoms in the films. The reasons may be as follows: First, some $\mathrm{Cu}$ atoms combine with oxygen atoms in the vacuum chamber to form $\mathrm{Cu}-\mathrm{O}$, and oxygen originates from the background atmosphere of the vacuum chamber. Second, a very small amount of $\mathrm{Cu}$ atoms is deposited directly on the substrate before it reacts with nitrogen in the vacuum chamber. In addition, other phases such as $\mathrm{Cu}_{4} \mathrm{~N}$ may exist in the films [36], causing it to deviate from the stoichiometric ratio of 3:1. The corresponding EDS elemental mapping of the surface of the $\mathrm{Cu}_{3} \mathrm{~N}$ films is shown in Figure $2 \mathrm{~b}$. 

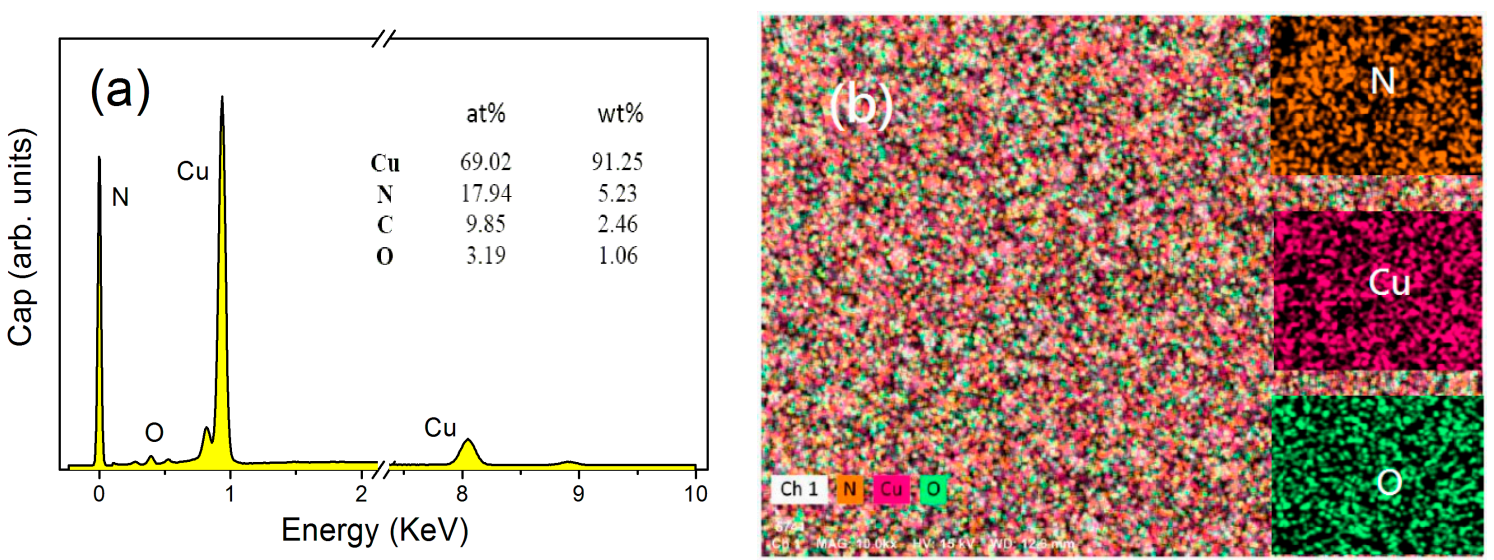

Figure 2. (a) Energy disperse spectra (EDS) results of $\mathrm{Cu}_{3} \mathrm{~N}$ films prepared at $r=1 / 3$, and the inserted value are the atomic and mass percentages of various atoms in the $\mathrm{Cu}_{3} \mathrm{~N}$ films; $(\mathbf{b})$ corresponding EDS elemental mapping of the surface of the $\mathrm{Cu}_{3} \mathrm{~N}$ films.

Figure 3 a shows the $X R D$ results of the $\mathrm{Cu}_{3} \mathrm{~N}$ films. The diffraction peaks of the crystal planes of $\mathrm{Cu}_{3} \mathrm{~N}$ crystals are sharp, which indicates that the $\mathrm{Cu}_{3} \mathrm{~N}$ films prepared by magnetron sputtering has a good crystallinity under different $r$. When $r$ is small, the $\mathrm{Cu}_{3} \mathrm{~N}$ films show preferential growth in the crystal planes of (100) and (200). By contrast, the films show preferential growth the crystal plane of (110). This result is similar to most research reports, which indicate that $\mathrm{Cu}_{3} \mathrm{~N}$ prepared by magnetron sputtering has an anti- $\mathrm{ReO}_{3}$ structure $[19,31,37]$. The reason for the preferential growth orientation of the $\mathrm{Cu}_{3} \mathrm{~N}$ films is as follows: At low $r$, films are mainly formed by $\mathrm{Cu}-\mathrm{N}$ bonds due to the adsorption of nitrogen atoms into the crystal lattice of $\mathrm{Cu}$ atoms; and then $\mathrm{Cu}_{3} \mathrm{~N}(100)$ and $\mathrm{Cu}_{3} \mathrm{~N}$ (200) planes are grown. At high $r$, sufficient nitrogen atoms combine with $\mathrm{Cu}$ on the target surface or substrate surface to form $\mathrm{Cu}-\mathrm{N}$. The $\mathrm{Cu}_{3} \mathrm{~N}$ (110) plane is grown on the films according to the principle that the free energy of the crystal plane has the lowest priority. Another explanation is that as the flow of nitrogen increases, the number of $\mathrm{Cu}$ atoms reaching the surface of the substrate decreases. As such, insufficient $\mathrm{Cu}$ atoms combine with high-energy nitrogen, resulting in the weakening of the $\mathrm{Cu}_{3} \mathrm{~N}$ (110) peak intensity $[28,31]$. When the experimental parameters change, the preferential growth of the $\mathrm{Cu}_{3} \mathrm{~N}$ crystal plane shifts from (100) to (111) [38]. This phenomenon may be caused by different preparation methods employed. At the same time, it is not difficult to find that there are two very weak diffraction peaks around $31.5^{\circ}$ and $48.1^{\circ}$, which belong to the diffraction peaks of $\mathrm{CuO}$ and $\mathrm{Cu}$, respectively [39]. The XRD diffraction pattern of the $\mathrm{TiO}_{2}$ films is shown in Figure 3b. The peaks at $25.3^{\circ}, 38.0^{\circ}, 48.1^{\circ}$, and $53.3^{\circ}$ correspond to the diffraction peaks of the (101), (112), (200), and (211) crystal planes of $\mathrm{TiO}_{2}[8,40]$, respectively, which belong to anatase $\mathrm{TiO}_{2}$ as referred to JCPDS card (NO. 21-1272). The peaks at $54.8^{\circ}$ correspond to the diffraction peak of the (211) crystal plane of $\mathrm{TiO}_{2}$, belonging to the tetragonal rutile phase [9]. The main body of the $\mathrm{TiO}_{2}$ films prepared by magnetron sputtering is anatase structure. Compared with rutile, anatase has more oxygen vacancies and can easily trap electrons, resulting in better electron-hole separation effect [41].

Figure 4a shows the survey scan of the XPS spectrum of $\mathrm{Cu}_{3} \mathrm{~N}$ films prepared at different $r$ values. A strong oxygen peak appears in the spectrum, indicating that the surface of the films contains more oxygen. Oxygen mainly originates from the moisture and atmospheric absorption of the films and the residual oxygen in the vacuum chamber. As the $r$ increases, the CuLMM peak and Cu2P peak in the films increase significantly, thereby indicating that increasing flow rate of $\mathrm{N}_{2}$ is more favorable for the formation of $\mathrm{Cu}_{3} \mathrm{~N}$ structure by nitrogen and $\mathrm{Cu}$ atoms in the vacuum chamber. To analyze the bonding mode and valence state of $\mathrm{Cu}$ in the films, we performed Lorentz fitting on the Cu2P peak of the XPS spectrum. Figure $4 \mathrm{~b}$ shows the XPS fitting of $\mathrm{Cu} 2 \mathrm{P}$ for the $\mathrm{Cu}_{3} \mathrm{~N}$ films. In the range of 930.0-940.0 eV, the spectral line can be fitted by two $\mathrm{Cu}$ characteristic peaks, namely, $\mathrm{Cu}^{2+} \mathrm{Cu} 2 \mathrm{P}_{3 / 2}$ $(334.5 \mathrm{eV})$ and $\mathrm{Cu}^{1+} \mathrm{Cu} 2 \mathrm{P}_{3 / 2}(333.0 \mathrm{eV})$, indicating that the valence of $\mathrm{Cu}$ on the surface of the films is 
+2 or $+1[42,43]$. At the same time, according to the fitting results, we obtained by simple estimation that the ratio of $\mathrm{Cu}^{1+}$ to $\mathrm{Cu}^{2+}$ in the films deposited under the conditions of $r=1 / 1$ and $r=1 / 3$ is 3.66 and 0.69 , respectively. As the nitrogen pressure in the vacuum chamber decreases, the $\mathrm{Cu}^{+}$component in the films decreases. Figure $4 \mathrm{c}$ shows the N1s in the $\mathrm{Cu}_{3} \mathrm{~N}$ films. The peak of binding energy of $\mathrm{N}$ is mainly at $400.0 \mathrm{eV}$, and the peak at $397.8 \mathrm{eV}$ is relatively small. The binding energy at $397.8 \mathrm{eV}$ indicates that the nitrogen atom in the form of beta- $\mathrm{N}(\beta-\mathrm{N})$ exists in the crystal, and that at $400.0 \mathrm{eV}$ indicates that the nitrogen atom in the form of gamma-N $(\gamma-\mathrm{N})$ exists in the crystal or in the form of N-N and N-O bond [44]. Similarly, according to the Lorentz fitting results of the N1s peak, the ratio of $\beta-\mathrm{N}$ to $\gamma-\mathrm{N}$ in the films deposited under the conditions of $r=1 / 1$ and $r=1 / 3$ is estimated to be 2.68 and 2.03 , respectively.

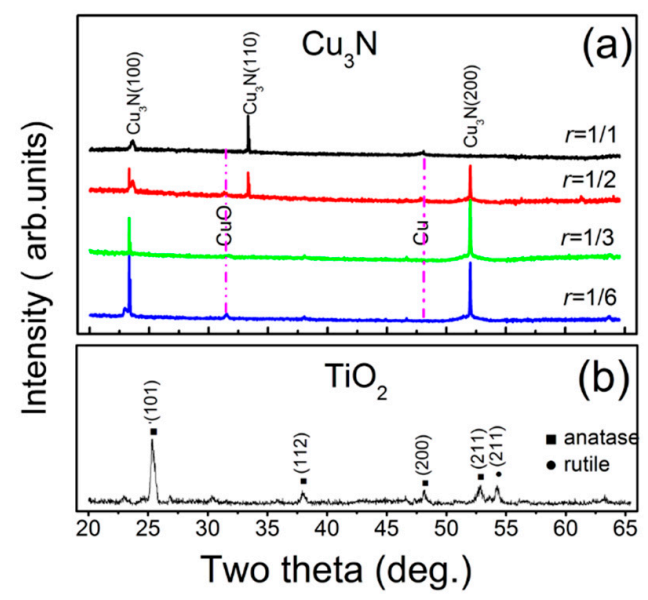

Figure 3. XRD diffraction patterns of films deposited by magnetron sputtering (a) $\mathrm{Cu}_{3} \mathrm{~N}$ and (b) $\mathrm{TiO}_{2}$.
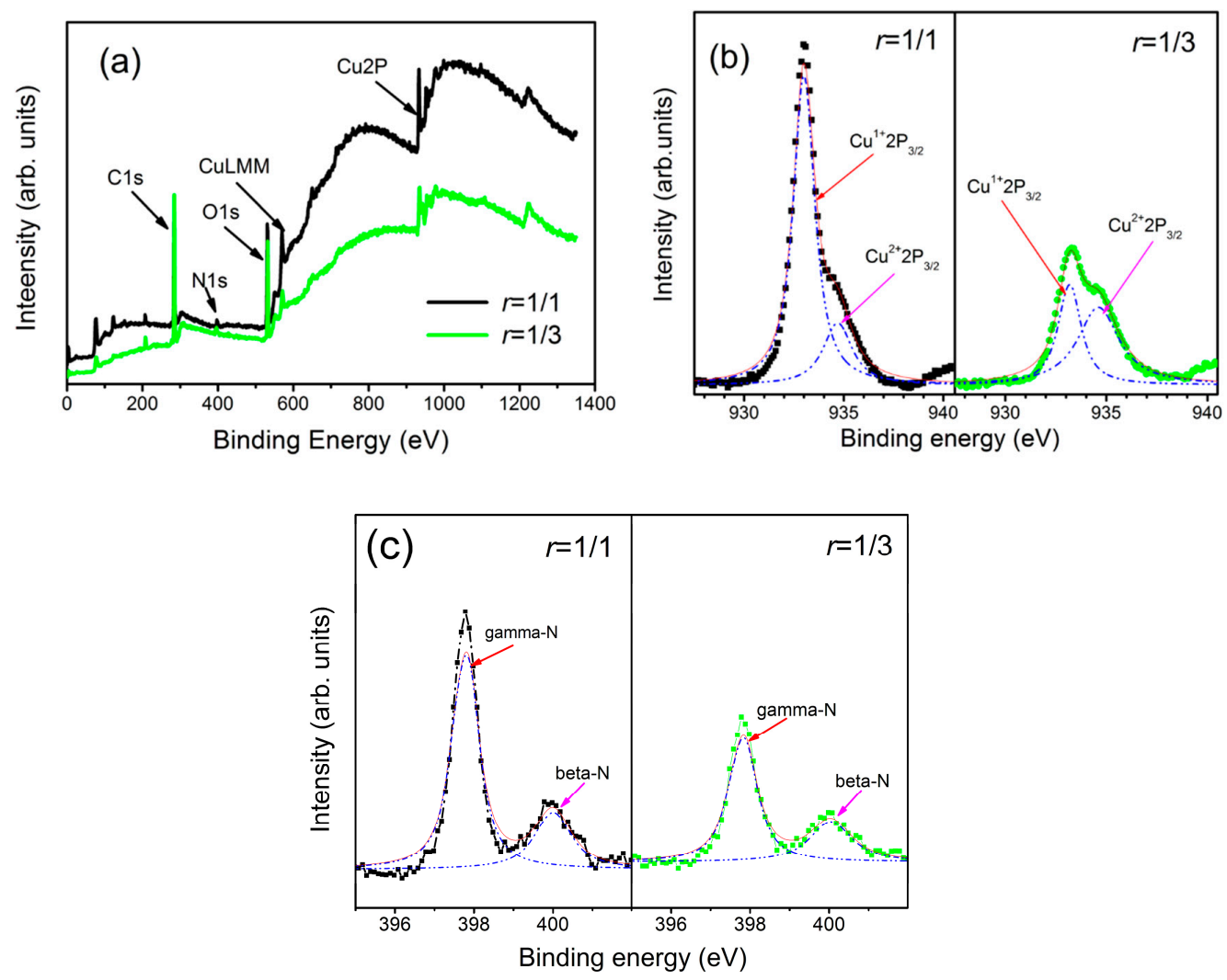

Figure 4. XPS spectra of $\mathrm{Cu}_{3} \mathrm{~N}$ films deposited by $r=1 / 1$ and $r=1 / 3$ : (a) Survey, (b) deconvoluted Cu2p spectra, and (c) deconvoluted N1s spectra. 
Figure 5a shows the UV-vis absorption spectrum of the $\mathrm{Cu}_{3} \mathrm{~N}$ films. The films show good absorption in the visible light band, indicating its feasibility for catalytic application to visible light. The absorption coefficient $\alpha$ of the $\mathrm{Cu}_{3} \mathrm{~N}$ films can be obtained directly by the absorption spectrum of the films as follows:

$$
\alpha=\ln \left(\frac{100}{T}\right) / d
$$

where $T$ and $d$ are the transmittance and thickness of the $C u_{3} N$ films. The optical band gap $\left(E_{g}\right)$ of the $\mathrm{Cu}_{3} \mathrm{~N}$ films can be obtained by the Tauc equation as follows:

$$
\alpha h v=A\left(h v-E_{g}\right)^{2}
$$

where $h, v$, and $A$ are the Planck constant, optical frequency, and constant, respectively. The $E_{g}$ of the films prepared by magnetron sputtering is within 1.96-2.09 eV (Figure 5b), and the result is slightly larger than that in literature $[28,45,46]$. The reason may be caused by different preparation techniques and preparation parameters.
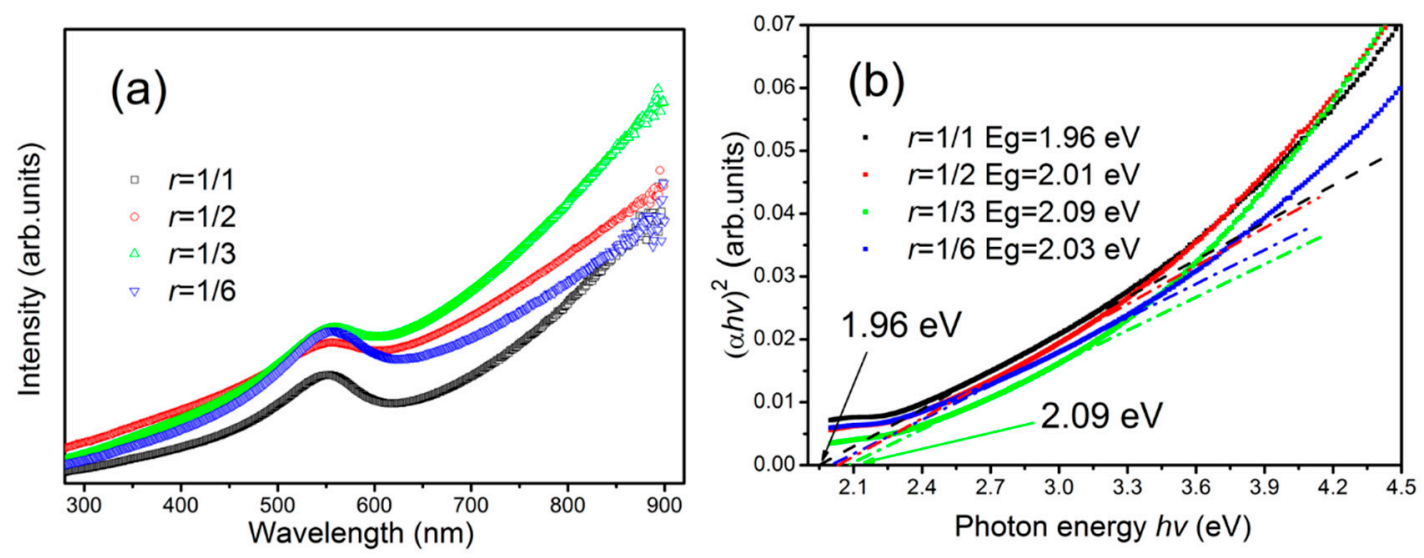

Figure 5. UV-vis transmission spectra of the $\mathrm{Cu}_{3} \mathrm{~N}$ films prepared at different $r(\mathbf{a})$, and determination of the optical band gap of the films (b).

The photoluminescence (PL) spectra of $\mathrm{Cu}_{3} \mathrm{~N}$ films prepared under different $r$ at 370 nm excitation wavelength are shown in Figure 6. The room-temperature PL bands of the $\mathrm{Cu}_{3} \mathrm{~N}$ films prepared under different $r$ are mainly concentrated in the blue-violet light region. The PL spectrum of the sample shows three peaks that are located at 418,488 , and $507 \mathrm{~nm}$. The peak position at $418 \mathrm{~nm}$ is very strong, and the peak positions at 488 and $507 \mathrm{~nm}$ are relatively weak. We think that the peak position at $418 \mathrm{~nm}$ is a band-edge emission of the $\mathrm{Cu}_{3} \mathrm{~N}$ films, and the two other peaks are caused by defect-state fluorescence [28]. The change in $r$ has little effect on the intensity of each luminous peak. Based on this spectrum, the intrinsic luminescence energy gap of the $\mathrm{Cu}_{3} \mathrm{~N}$ film is within 2.34-2.97 eV, which is higher than the optical band gap $E_{g}$ obtained in Figure 5b (1.96-2.09 eV) [47,48]. The energy level difference is about $0.6 \mathrm{eV}$. The light emitting region of $\mathrm{Cu}_{3} \mathrm{~N}$ in the blue-violet light range is mainly due to the following: Unbonded $\mathrm{Cu}$ atoms (which can be regarded as self-doping) that form the electronic transition from the defect level to the valence band [49]; the energy levels of the center vacancy defects in the $\mathrm{Cu}$ nitride crystal and the electronic transitions between the composite defects; and the electronic transitions between the interface defects near the $\mathrm{Cu}_{3} \mathrm{~N}$ grain boundary and the valence band [28].

The degradation rate reaches $99.8 \%$ when $r=1 / 3$. As shown in Figure 7 , the photodegradation rate of methyl orange increases with the extension of the illumination time. The photocatalytic degradation rate of methyl orange on the films reaches $93.5 \%$ after $30 \mathrm{~min}$ of illumination, and $r=1 / 3$ is the best photocatalytic activity (degradation rate reaches $99.5 \%$ ). This finding is due to the large number of voids and free $\mathrm{Cu}$ coexisting in the $\mathrm{Cu}$ nitride structure prepared at $r=1 / 3$, and the combination of the two exhibits good photocatalytic activity. The superior photocatalytic properties of the $\mathrm{Cu}_{3} \mathrm{~N}$ films are 
mainly due to its special anti- $\mathrm{ReO}_{3}$ lattice structure. In $\mathrm{Cu}_{3} \mathrm{~N}$ crystals, $\mathrm{Cu}$ atoms do not occupy the tight position of the lattice (111) plane but leave many voids in their crystal structure, causing the other atoms to easily fill the central vacancy of the $\mathrm{Cu}_{3} \mathrm{~N}$ lattice. After this void is filled with other atoms, structural defects or impurity replacement defects are formed in the $\mathrm{Cu}_{3} \mathrm{~N}$ crystal. The presence of these defects plays an important role in photocatalysis.

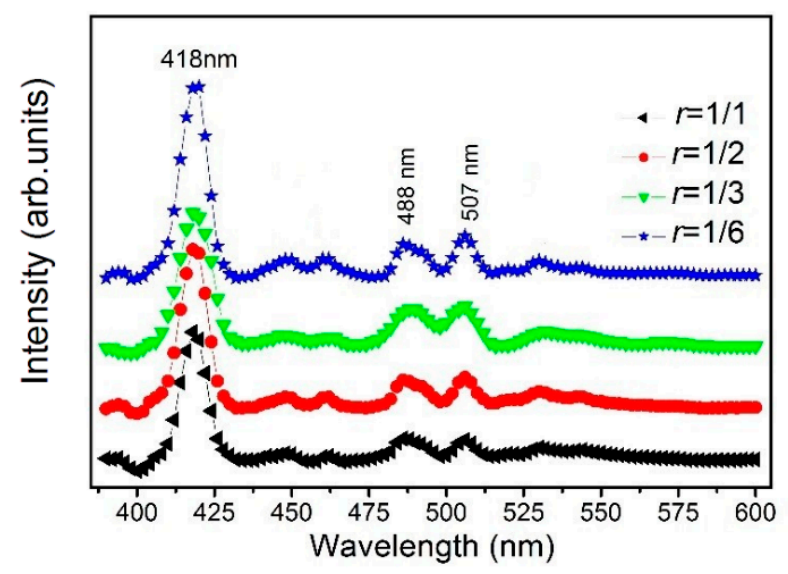

Figure 6. Photoluminescence spectra of $\mathrm{Cu}_{3} \mathrm{~N}$ films prepared at different values of $r$.
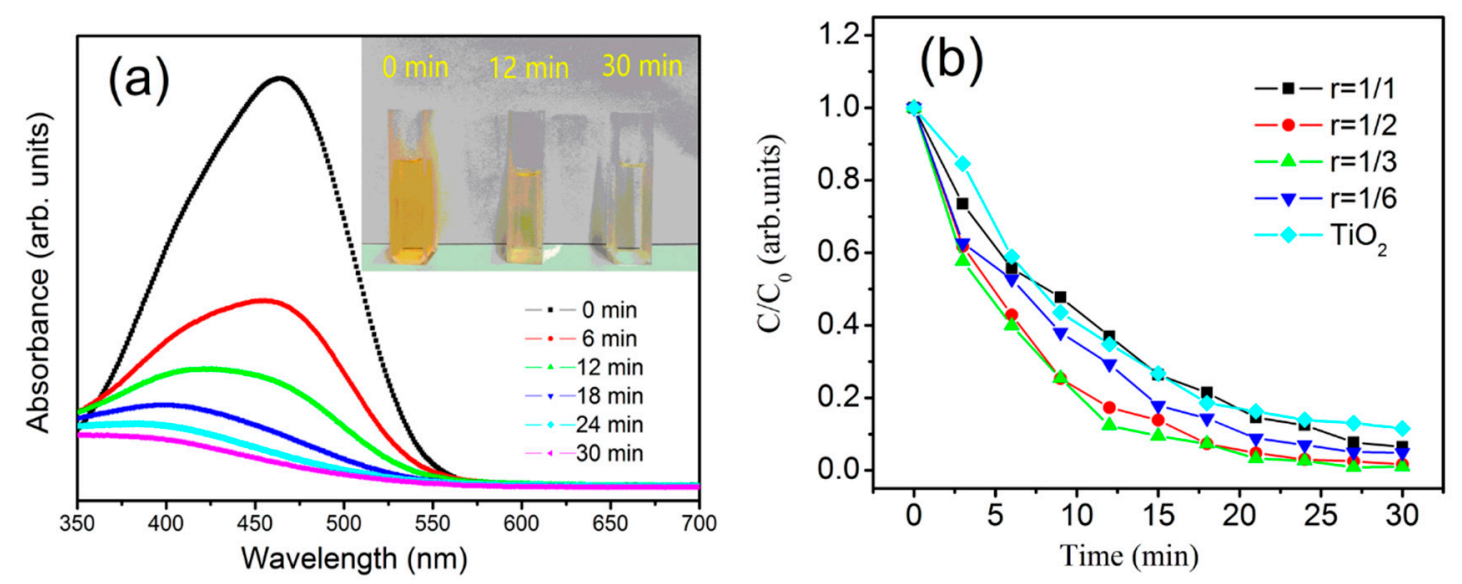

Figure 7. (a) Methyl orange absorbance of the films prepared at $r=1 / 3$ at different times; (b) curve of methyl orange degradation by films prepared at different levels of $r$. For comparison, the degradation curves of the $\mathrm{TiO}_{2}$ films are presented.

A schematic of the degradation of methyl orange by the $\mathrm{Cu}_{3} \mathrm{~N}$ films is shown in Figure 8 . In photocatalysis, the formation of $\bullet \mathrm{OH}$ free radicals is very important [50]. Each $\mathrm{Cu}_{3} \mathrm{~N}$ particle in the films can be regarded as a small short-circuit photoelectrochemical cell, which can generate wide-ranging electrons $\left(e^{-}\right)$and holes $\left(h^{+}\right)$under the photoelectric effect. The $e^{-}$and $h^{+}$migrate to different positions on the surface of the $\mathrm{Cu}_{3} \mathrm{~N}$ grains under the action of the electric field. The photo-generated electrons $e^{-}$on the surface of the $\mathrm{Cu}_{3} \mathrm{~N}$ grains are easily captured by oxidizing substances, such as dissolved oxygen in the water. The $h^{+}$can oxidize organic substances adsorbed on the surface of the $\mathrm{Cu}_{3} \mathrm{~N}$ grains or first oxidize $\cdot \mathrm{OH}$ and $\mathrm{H}_{2} \mathrm{O}$ molecules adsorbed on the surface of the $\mathrm{Cu}_{3} \mathrm{~N}$ grains into $\cdot \mathrm{OH}$ radicals. The oxidizing ability of $\cdot \mathrm{OH}$ radical is the strongest among the oxidants in the water body, and it can oxidize most of organic matter and inorganic pollutants in the water and mineralize them into inorganic small molecules, carbon dioxide, water, and other harmless substances. The possible chemical formulas are as follows:

$$
\mathrm{Cu}_{3} \mathrm{~N}+h v \rightarrow h^{+}+e^{-}
$$




$$
\begin{aligned}
h^{+}+\mathrm{OH}^{-} & \rightarrow \cdot \mathrm{OH} \\
h^{+}+\mathrm{H}_{2} \mathrm{O} & \rightarrow \cdot \mathrm{OH}+\mathrm{H}^{+} \\
e^{-}+\mathrm{O}_{2} & \rightarrow \cdot \mathrm{O}_{2}^{-} \\
\mathrm{OH}+\mathrm{H}^{+} \text {dye } \rightarrow \cdots & \rightarrow \mathrm{CO}_{2}+\mathrm{H}_{2} \mathrm{O} .
\end{aligned}
$$

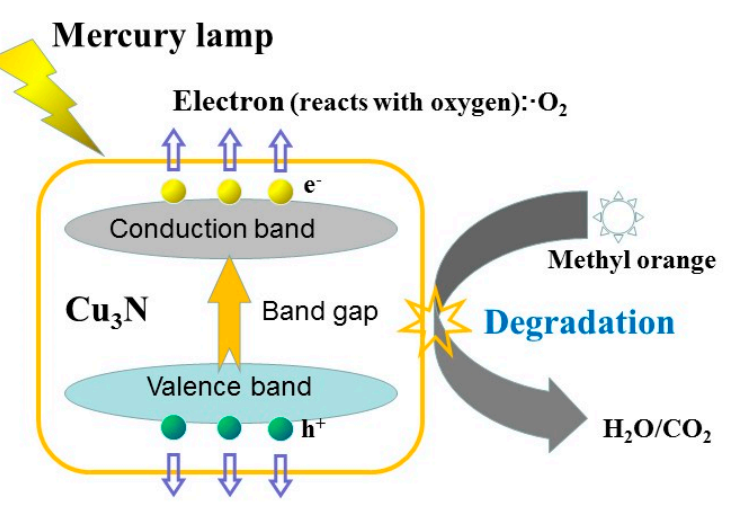

Cavity (react with water): $\cdot \mathbf{O H}$

Figure 8. Scheme of photocatalytic degradation of methyl orange solution by the $\mathrm{Cu}_{3} \mathrm{~N}$ films.

The superior photocatalytic degradation activity of the $\mathrm{Cu}_{3} \mathrm{~N}$ films can be explained by frontier molecular orbital theory [51,52]. In this photocatalytic reaction system, the 2P electron orbital of oxygen atom is the frontier molecular orbit (HOMO), and the metal $\mathrm{Cu}$ orbital in the films is the lowest unoccupied molecular orbital (LUMO). The electrons are transitioned from the oxygen atom under specific wavelength illumination. For the $\mathrm{Cu}$ atom, the atomic HOMO needs to reach stable electrons to form $\cdot \mathrm{OH}$ with e in water molecules, thereby effectively degrading the methyl orange molecule and achieving the photocatalytic effect.

\section{Conclusions}

$\mathrm{Cu}_{3} \mathrm{~N}$ films were prepared by magnetron sputtering on silicon and quartz substrate under different gas flow ratios. Characterization and analysis of the microstructure and optical properties of the films were performed using modern analytical testing techniques and methods. The $\mathrm{Cu}_{3} \mathrm{~N}$ films prepared in this work have a good crystalline phase and present an anti- $\mathrm{ReO}_{3}$ crystal structure. $\mathrm{The} \mathrm{Cu}_{3} \mathrm{~N}$ films contains $\mathrm{Cu}$-rich atoms and have part of structure vacancies. These defects play a decisive role with regard to the structure and light absorption properties of the films. Experimental results show that under the irradiation of mercury lamp, the degradation rate of methyl orange by the $\mathrm{Cu}_{3} \mathrm{~N}$ films can reach more than $99.5 \%$ (when $r=1 / 3$, the best effect is achieved), which is superior to that of $\mathrm{TiO}_{2}$ films with the same thickness prepared by magnetron sputtering. This finding is due to the presence of more defects and $\mathrm{Cu}$-rich atoms in the films, resulting in effective separation of photogenerated electron-hole pairs. This phenomenon also expands the absorption band edge red shift, enhances the light absorption ability, and confers excellent photocatalytic performance. Hence, the fabricated $\mathrm{Cu}_{3} \mathrm{~N}$ films can oxidize pollutants into carbon dioxide and water for effective degradation and would be a promising low cost and nontoxic material for photocatalysis.

Author Contributions: Formal analysis, S.M.; Investigation, H.S. and L.Z.; Project administration, J.X.; Writing -original draft, A.J. All authors have read and agreed to the published version of the manuscript.

Funding: This research was funded by the National Natural Science Foundation of China (No. 11364011) and the Guangxi Natural Science Foundation (Grants No. 2017GXNSFAA 198121).

Conflicts of Interest: The authors declare no conflict of interest. 


\section{References}

1. Ren, X.; Qi, X.; Shen, Y.; Xiao, S.; Xu, G.; Zhang, Z.; Huang, Z.; Zhong, J. 2D co-catalytic MoS2nanosheets embedded with 1D TiO2nanoparticles for enhancing photocatalytic activity. J. Phys. D Appl. Phys. 2016, 49, 315304. [CrossRef]

2. Ge, M.; Cai, J.; Iocozzia, J.; Cao, C.; Huang, J.; Zhang, X.; Shen, J.; Wang, S.; Zhang, S.; Zhang, K.-Q.; et al. A review of $\mathrm{TiO}_{2}$ nanostructured catalysts for sustainable $\mathrm{H} 2$ generation. Int. J. Hydrog. Energy 2017, 42, 8418-8449. [CrossRef]

3. Yang, H.G.; Sun, C.; Qiao, S.-Z.; Zou, J.; Liu, G.; Smith, S.C.; Cheng, H.-M.; Lu, G. Anatase TiO 2 single crystals with a large percentage of reactive facets. Nature 2008, 453, 638-641. [CrossRef]

4. Wang, X.; Yang, B.; Zhou, K.; Zhang, D.; Li, Z.; Zhou, C. Ordered porous $\mathrm{TiO}_{2}$ films obtained by freezing and the application in dye sensitized solar cells. Curr. Appl. Phys. 2015, 15, 662-668. [CrossRef]

5. Huang, J.; Shen, J.; Li, S.; Cai, J.; Wang, S.; Lu, Y.; He, J.; Carmalt, C.J.; Parkin, I.P.; Lai, Y. TiO 2 nanotube arrays decorated with $\mathrm{Au}$ and Bi2S3 nanoparticles for efficient $\mathrm{Fe}^{3+}$ ions detection and dye photocatalytic degradation. J. Mater. Sci. Technol. 2020, 39, 28-38. [CrossRef]

6. Ansari, S.A.; Khan, M.M.; Ansari, M.O.; Cho, M.H. Nitrogen-doped titanium dioxide $\left(\mathrm{N}\right.$-doped $\left.\mathrm{TiO}_{2}\right)$ for visible light photocatalysis. New J. Chem. 2016, 40, 3000-3009. [CrossRef]

7. Hu, X.; Xiong, J.; Tang, Y.; Zhou, C.; Yang, J. Interface modification of polymer solar cells using graphene oxide and $\mathrm{TiO}_{2}$ NPs. Phys. Status Solidi 2014, 212, 585-590. [CrossRef]

8. Xu, L.; Wan, F.; Rong, Y.; Chen, H.; He, S.; Xu, X.; Liu, G.; Han, H.; Yuan, Y.; Yang, J.; et al. Stable monolithic hole-conductor-free perovskite solar cells using $\mathrm{TiO}_{2}$ nanoparticle binding carbon films. Org. Electron. 2017, 45, 131-138. [CrossRef]

9. Zhang, D.; Liu, W.; Tang, L.; Zhou, K.; Luo, H. High performance capacitors via aligned $\mathrm{TiO}_{2}$ nanowire array. Appl. Phys. Lett. 2017, 110, 133902. [CrossRef]

10. Cheng, L.; Xiang, Q.; Liao, Y.; Zhang, H. CdS-Based photocatalysts. Energy Environ. Sci. 2018, 11, $1362-1391$. [CrossRef]

11. Zhu, B.; Wang, F.; Zhang, K.; Zhang, J.; Gu, Y. Enhanced three-photon absorption in CdSe/CdS core/shell nanocrystals in near-infrared. Appl. Phys. Express 2016, 9, 82602. [CrossRef]

12. Gou, G.; Dai, G.; Wang, X.; Chen, Y.; Qian, C.; Kong, L.; Sun, J.; Yang, J. High-performance and flexible photodetectors based on $\mathrm{P}_{3} \mathrm{HT} / \mathrm{CdS} / \mathrm{CdS}: \mathrm{SnS}_{2}$ superlattice nanowires hybrid films. Appl. Phys. A 2017, 123, 731. [CrossRef]

13. Gou, G.; Dai, G.; Qian, C.; Liu, Y.; Fu, Y.; Tian, Z.; He, Y.; Kong, L.; Yang, J.; Sun, J.; et al. High-performance ultraviolet photodetectors based on CdS/CdS:SnS 2 superlattice nanowires. Nanoscale 2016, 8, 14580-14586. [CrossRef] [PubMed]

14. Kim, K.J.; Kim, J.H.; Kang, J.H. Structural and optical characterization of $\mathrm{Cu}_{3} \mathrm{~N}$ films prepared by reactive RF magnetron sputtering. J. Cryst. Growth 2001, 222, 767-772. [CrossRef]

15. Jiang, A.; Qi, M.; Xiao, J. Preparation, structure, properties, and application of copper nitride $\left(\mathrm{Cu}_{3} \mathrm{~N}\right)$ thin films: A review. J. Mater. Sci. Technol. 2018, 34, 1467-1473. [CrossRef]

16. Yu, A.; Hu, R.; Liu, W.; Zhang, R.; Zhang, J.; Pu, Y.; Chu, L.; Yang, J.; Li, X. Preparation and characterization of Mn doped copper nitride films with high photocurrent response. Curr. Appl. Phys. 2018, 18, 1306-1312. [CrossRef]

17. Yee, Y.S.; Inoue, H.; Hultqvist, A.; Hanifi, D.; Salleo, A.; Magyari-Kope, B.; Nishi, Y.; Bent, S.F.; Clemens, B.M. Copper interstitial recombination centers in $\mathrm{Cu}_{3}$ N. Phys. Rev. B 2018, 97, 245201. [CrossRef]

18. Maruyama, T.; Morishita, T. Copper nitride thin films prepared by radio-frequency reactive sputtering. J. Appl. Phys. 1995, 78, 4104-4107. [CrossRef]

19. Jiang, A.; Xiao, J.; Gong, C.; Wang, Z.; Ma, S. Structure and electrical transport properties of Pb-doped copper nitride $\left(\mathrm{Cu}_{3} \mathrm{~N}: \mathrm{Pb}\right)$ films. Vacuum 2019, 164, 53-57. [CrossRef]

20. Kuzmin, A.; Kalinko, A.; Anspoks, A.; Timoshenko, J.; Kalendarev, R. Study of Copper Nitride Thin Film Structure. Latv. J. Phys. Tech. Sci. 2016, 53, 31-37. [CrossRef]

21. Timoshenko, J.; Anspoks, A.; Kalinko, A.; Kuzmin, A. Thermal disorder and correlation effects in anti-perovskite-type copper nitride. Acta Mater. 2017, 129, 61-71. [CrossRef] 
22. Wu, Z.; Chen, H.; Gao, N.; Yang, J.; Yang, T.; Zhang, J.; Li, X.; Yao, K. Ab initio calculations of the structural, elastic, electronic and optical properties of $\mathrm{Cu}_{3} \mathrm{NM}$ compounds doped with $\mathrm{M}=\mathrm{Sc}, \mathrm{Y}$ and La. Solid State Commun. 2015, 201,9-14. [CrossRef]

23. Xiao, J.; Qi, M.; Gong, C.; Wang, Z.; Jiang, A.; Ma, J.; Cheng, Y. Crystal structure and optical properties of silver-doped copper nitride films $\left(\mathrm{Cu}_{3} \mathrm{~N}\right.$ :Ag) prepared by magnetron sputtering. J. Phys. D Appl. Phys. 2018, 51, 055305. [CrossRef]

24. Majumdar, A.; Drache, S.; Wulff, H.; Mukhopadhyay, A.K.; Bhattacharyya, S.; Helm, C.A.; Hippler, R. Strain Effects by Surface Oxidation of Cu3N Thin Films Deposited by DC Magnetron Sputtering. Coatings 2017, 7, 64. [CrossRef]

25. Yu, A.; Ma, Y.; Chen, A.; Li, Y.; Zhou, Y.; Wang, Z.; Zhang, J.; Chu, L.; Yang, J.; Li, X. Thermal stability and optical properties of Sc-doped copper nitride films. Vacuum 2017, 141, 243-248. [CrossRef]

26. Szczęsny, R.; Szłyk, E.; Wiśniewski, M.A.; Hoang, T.K.A.; Gregory, D.H. Facile preparation of copper nitride powders and nanostructured films. J. Mater. Chem. C 2016, 4, 5031-5037. [CrossRef]

27. Yuan, X.; Yan, P.; Liu, J. Preparation and characterization of copper nitride films at various nitrogen contents by reactive radio-frequency magnetron sputtering. Mater. Lett. 2006, 60, 1809-1812. [CrossRef]

28. Xiao, J.; Qi, M.; Cheng, Y.; Jiang, A.; Zeng, Y.; Ma, J. Influences of nitrogen partial pressure on the optical properties of copper nitride films. RSC Adv. 2016, 6, 40895-40899. [CrossRef]

29. Maruyama, T.; Morishita, T. Copper nitride and tin nitride thin films for write-once optical recording media. Appl. Phys. Lett. 1996, 69, 890-891. [CrossRef]

30. Asano, M.; Umeda, K.; Tasaki, A. Cu3N Thin Film for a New Light Recording Media. Jpn. J. Appl. Phys. 1990, 29, 1985-1986. [CrossRef]

31. Wang, J.; Chen, J.; Yuan, X.; Wu, Z.; Miao, B.; Yan, P. Copper nitride $\left(\mathrm{Cu}_{3} \mathrm{~N}\right)$ thin films deposited by RF magnetron sputtering. J. Cryst. Growth 2006, 286, 407-412. [CrossRef]

32. Wang, T.; Pan, X.; Wang, X.; Duan, H.; Li, R.; Li, H.; Xie, E. Field emission property of copper nitride thin film deposited by reactive magnetron sputtering. Appl. Surf. Sci. 2008, 254, 6817-6819. [CrossRef]

33. Wang, J.; Li, F.; Liu, X.; Zhou, H.; Shao, X.; Qu, Y.; Fan, Y. Cu3N and its analogs: A new class of electrodes for lithium ion batteries. J. Mater. Chem. A 2017, 5, 8762-8768. [CrossRef]

34. Li, X.; Hector, A.L.; Owen, J. Evaluation of $\mathrm{Cu} 3 \mathrm{~N}$ and $\mathrm{CuO}$ as Negative Electrode Materials for Sodium Batteries. J. Phys. Chem. C 2014, 118, 29568-29573. [CrossRef]

35. Greczynski, G.; Hultman, L. X-ray photoelectron spectroscopy: Towards reliable binding energy referencing. Prog. Mater. Sci. 2020, 107, 100591. [CrossRef]

36. Zhou, Q.; Lu, Q.; Zhou, Y.; Yang, Y.; Du, X.; Zhang, X.; Wu, X.-J. Influences of preparation methods on bipolar switching properties in copper nitride films. Surf. Coatings Technol. 2013, 229, 135-139. [CrossRef]

37. Samaniego-Benítez, J.E.; Chavez-Urbiola, I.; Ramirez-Aparicio, J.; Perez-Robles, J.; Ramírez-Bon, R. Thermal transformation of plumbonacrite/Si films into microstructured Pb/Si ones. Mater. Lett. 2017, 198, $38-41$. [CrossRef]

38. Nowakowska-Langier, K.; Chodun, R.; Minikayev, R.; Okrasa, S.; Strzelecki, G.W.; Wicher, B.; Zdunek, K. Copper nitride layers synthesized by pulsed magnetron sputtering. Thin Solid Films 2018, 645, 32-37. [CrossRef]

39. Deng, X.; Wei, Z.; Cui, C.; Liu, Q.; Wang, C.; Ma, J. Oxygen-deficient anatase $\mathrm{TiO}_{2} @ \mathrm{C}$ nanospindles with pseudocapacitive contribution for enhancing lithium storage. J. Mater. Chem. A 2018, 6, 4013-4022. [CrossRef]

40. Setvin, M.; Franchini, C.; Hao, X.; Schmid, M.; Janotti, A.; Kaltak, M.; Van De Walle, C.G.; Kresse, G.; Diebold, U. Direct View at Excess Electrons inTiO 2 Rutile and Anatase. Phys. Rev. Lett. 2014, 113, 086402. [CrossRef]

41. Akira, M.; Takahiro, T.; Nobuhiro, K. Synthesis of $\mathrm{Cu} 3 \mathrm{~N}$ from $\mathrm{CuO}$ and $\mathrm{NaNH}_{2}$. J. of Asian Ceram. Soc. 2014, 2, 326-328.

42. Parida, S.K.; Medicherla, V.R.R.; Mishra, D.K.; Choudhary, S.; Solanki, V.; Varma, S. Low energy ion beam modification of $\mathrm{Cu} / \mathrm{Ni} / \mathrm{Si}(100)$ surface. Bull. Mater. Sci. 2014, 37, 1569-1573. [CrossRef]

43. Morales, J.; Espinós, J.P.; Caballero, A.; Gonzalez-Elipe, A.R.; Mejías, J.A.; González-Elipe, A.R. XPS Study of Interface and Ligand Effects in Supported $\mathrm{Cu}_{2} \mathrm{O}$ and $\mathrm{CuO}$ Nanometric Particles. J. Phys. Chem. B 2005, 109, 7758-7765. [CrossRef] [PubMed] 
44. Wang, H.-Q.; Yan, J.-P.; Zhang, Z.-M.; Chang, W.-F. Photocatalytic activity of N-doped $\mathrm{TiO}_{2}$ : Photocatalytic synthesis of o-aminophenol at room temperature. React. Kinet. Catal. Lett. 2009, 97, 91-99. [CrossRef]

45. Hadian, F.; Rahmati, A.; Movla, H.; Khaksar, M. Reactive DC magnetron sputter deposited copper nitride nano-crystalline thin films: Growth and characterization. Vacuum 2012, 86, 1067-1072. [CrossRef]

46. Nowakowska-Langier, K.; Skowroński, Ł.; Chodun, R.; Okrasa, S.; Strzelecki, G.W.; Wilczopolska, M.; Wicher, B.; Mirowski, R.; Zdunek, K. Influence of generation control of the magnetron plasma on structure and properties of copper nitride layers. Thin Solid Films 2020, 694, 137731. [CrossRef]

47. Sahoo, G.; Jain, M.K. Formation of $\mathrm{CuO}$ on thermal and laser-induced oxidation of $\mathrm{Cu}_{3} \mathrm{~N}$ thin films prepared by modified activated reactive evaporation. Appl. Phys. A 2014, 118, 1059-1066. [CrossRef]

48. Borsa, D.; Boerma, D. Growth, structural and optical properties of $\mathrm{Cu}_{3} \mathrm{~N}$ films. Surf. Sci. 2004, 548, 95-105. [CrossRef]

49. Tian, X.; Tang, H.; Luo, J.; Nan, H.; Shu, T.; Du, L.; Zeng, J.; Liao, S.; Adzic, R.R. High-Performance Core-Shell Catalyst with Nitride Nanoparticles as a Core: Well-Defined Titanium Copper Nitride Coated with an Atomic Pt Layer for the Oxygen Reduction Reaction. ACS Catal. 2017, 7, 3810-3817. [CrossRef]

50. Schneider, J.; Matsuoka, M.; Takeuchi, M.; Zhang, J.; Horiuchi, Y.; Anpo, M.; Bahnemann, D.W. Understanding TiO2Photocatalysis: Mechanisms and Materials. Chem. Rev. 2014, 114, 9919-9986. [CrossRef]

51. Tang, M.L.; Reichardt, A.D.; Wei, P.; Bao, Z. Correlating Carrier Type with Frontier Molecular Orbital Energy Levels in Organic Thin Film Transistors of Functionalized Acene Derivatives. J. Am. Chem. Soc. 2009, 131, 5264-5273. [CrossRef] [PubMed]

52. Herder, M.; Eisenreich, F.; Bonasera, A.; Grafl, A.; Grubert, L.; Patzel, M.; Schwarz, J.; Hecht, S. Light-controlled reversible modulation of frontier molecular orbital energy levels in trifluoromethylated diarylethenes. Chem. Eur. J. 2017, 23, 3743-3754. [CrossRef] [PubMed]

(C) 2020 by the authors. Licensee MDPI, Basel, Switzerland. This article is an open access article distributed under the terms and conditions of the Creative Commons Attribution (CC BY) license (http://creativecommons.org/licenses/by/4.0/). 